\title{
PEMANFAATAN PENILAIAN PORTOFOLIO DALAM MENINGKATKAN HASIL BELAJAR AKUNTANSI
}

\author{
Oleh \\ Sukanti ${ }^{1}$
}

\begin{abstract}
Abstrak
Hasil belajar dapat dikelompokkan menjadi tiga domain yaitu kognitif, afektif, dan psikomotor. Setiap domain disusun menjadi beberapa jenjang kemampuan, mulai dari hal yang sederhana sampai hal yang kompleks, mulai dari hal yang mudah sampai hal yang sukar, mulai dari hal yang konkrit sampai dengan hal yang abstrak. Kenyataan menunjukkan masih banyak guru yang dalam melakukan penilaian kurang memperhatikan prinsip penilaian secara menyeluruh tetapi hanya menekankan pada aspek kognitif dan psikomotor, penilaian afektif kurang mendapat perhatian, di samping itu penilaian proses kadang diabaikan, mereka lebih menekankan pada penilaian hasil dari pada proses. Penilaian portofolio mempunyai fungsi untuk mengurangi kelemahan ini. Proses pembelajaran akuntansi dilakukan secara tuntas karena mata pelajaran Akuntansi merupakan suatu siklus sehingga keterampilan yang satu berkaitan dengan keterampilan yang lain. Selain itu pembelajaran Akuntansi lebih mengutamakan pencapaian melalui pelatihan yang dialami langsung oleh siswa. Oleh karena itu penilaian yang dilakukan haruslah memperhatikan prinsip berkala dan berkesinambungan, dan penilaian secara menyeluruh. Sistem penilaian yang sebaiknya dikembangkan adalah penilaian portofolio. Pemanfaatan penilaian portofolio dalam meningkatkan hasil belajar dapat dilihat dari landasan pemikiran diterapkannya penilaian portofolio, prinsip penilaian portofolio, dan indikator penilaian portofolio. Landasan pemikiran diterapkannya penilaian portofolio adalah membelajarkan kembali dan merefleksi pengalaman belajar peserta didik. Prinsip penilaian portofolio adalah penilaian proses dan hasil pembelajaran, penilaian berkesinambungan. Indikator penilaian portofolio yang meliputi: tes formatif dan sumatif, tugas terstruktur, catatan perilaku peserta didik, dan aktivitas peserta didik di luar sekolah yang mendukung belajar.
\end{abstract}

Kata kunci: penilaian, portofolio, akuntansi, pemanfaatan.

\section{A. Pendahuluan}

Menurut Benyamin S. Bloom (1956) hasil belajar dapat dikelompokkan menjadi tiga domain yaitu kognitif, afektif, dan psikomotor. Setiap domain disusun menjadi beberapa jenjang kemampuan, mulai dari hal yang sederhana sampai hal yang kompleks, mulai dari hal yang mudah sampai hal yang sukar, mulai dari hal yang konkrit sampai dengan hal yang abstrak. Domain kognitif memiliki enam jenjang kemampuan yaitu pengetahuan, pemahaman, penerapan, analisis, sintesis, dan evaluasi. Domain afektif terdiri atas beberapa jenjang yaitu; kemauan menerima, kemauan menjawab, menilai, dan organisasi. Domain psikomotor yaitu kemampuan peserta didik yang berkaitan dengan gerakan tubuh atau bagian-bagiannya mulai dari gerakan yang sederhana sampai dengan gerakan yang kompleks (Zaenal Arifin, 2009). Kenyataan di lapangan menunjukkan sebagian besar guru dalam mengevaluasi hasil belajar belum melaksanakan evaluasi secara menyeluruh dari ketiga domain tersebut, bahkan hanya menekankan pada kognitif dan psikomotor, domain afektif

\footnotetext{
${ }^{1}$ Dosen Jurusan Pendidikan Akuntansi - Universitas Negeri Yogyakarta
} 
sering tidak mendapat perhatian. Selain itu penilaian proses kurang mendapat perhatian dibandingkan dengan penilaian hasil, pada hal pendidikan tidak hanya berorientasi pada hasil semata tetapi juga pada proses. Oleh karena itu perlu dipilih teknik penilaian yang menyeluruh dan penilaian hasil belajar menjadi bagian yang tidak terpisahkan dari proses pembelajaran. Evaluasi hasil belajar bertujuan untuk mengetahui tercapai tidaknya kompetensi dasar yang telah ditetapkan. Untuk mengetahui ketercapaian dapat digunakan berbagai teknik penilaian. Teknik penilaian portofolio merupakan teknik yang direkomendasikan dalam pembelajaran akuntansi karena akuntansi merupakan merupakan suatu siklus sehingga keterampilan yang satu berkaitan dengan keterampilan yang lain.Oleh karena itu penilaian yang sebaiknya dikembangkan adalah penilaian portofolio.

Guru sering mengikuti pelatihan penilaian portofolio, namun setelah selesai mengikuti pelatihan mereka kembali seperti semula yaitu memberikan tes tertulis pada tes formatif ataupun sumatif. Berikut ini akan disajikan pembahasan penilaian portofolio yang meliputi; konsep penilaian portofolio, tujuan penilaian portofolio, ciri-ciri penilaian portofolio, teknik penilaian portofolio, karakteristik mata pelajaran Akuntansi dan penggunaan penilaian portofolio dalam meningkatkan hasil belajar akuntansi.

\section{B. Pembahasan}

\section{Konsep Penilaian Portofolio}

Menurut Zaenal Arifin (2009) penilaian portofolio adalah suatu pendekatan atau model penilaian yang bertujuan untuk mengukur kemampuan peserta didik dalam membangun dan merefleksi suatu pekerjaan/tugas atau karya melalui pengumpulan bahan -bahan yang relevan dengan tujuan dan keinginan yang dibangun peserta didik sehingga hasil pekerjaan tersebut dapat dinilai dan dikomentari oleh guru dalam periode tertentu. Jadi penilaian portofolio merupakan suatu pendekatan dalam penilaian kinerja peserta didik atau digunakan untuk menilai kinerja. Sementara menurut Dasim Budimansyah (2002) penilaian portofolio adalah suatu usaha untuk memperoleh berbagai informasi secara berkala, berkesinambungan, dan menyeluruh tentang proses dan hasil pertumbuhan dan perkembangan wawasan pengetahuan, sikap dan keterampilan peserta didik yang bersumber dari catatan dan dokumentasi pengalaman belajarnya. Diknas (2007) penilaian portofolio merupakan penilaian berkelanjutan yang didasarkan pada kumpulan informasi dalam satu periode tertentu. Informasi tersebut dapat berupa karya peserta didik (hasil pekerjaan) dari proses pembelajaran yang dianggap terbaik oleh peserta didiknya, lembar jawaban tes yang menunjukkan soal yang mampu dan tidak mampu dijawab (bukan nilai) atau bentuk informasi lain yang terkait dengan kompetensi tertentu dalam satu mata pelajaran.

Penilaian portofolio pada dasarnya menilai karya peserta didik secara individu pada satu periode untuk suatu mata pelajaran. Portofolio sebagai alat penilaian telah dianjurkan untuk digunakan karena alasan berikut ini.

a. Memungkinkan peserta didik melakukan refleksi terhadap kemajuan belajarnya

b. Memungkinkan peserta didik memilih sendiri hasil karya yang menjadi isi portofolionya dan memberi alasan mengapa hasil karya itu penting

c. Peserta didik harus mampu menunjukkan kemampuan berfikir dan keterampilannya

d. Memberi gambaran atas apa yang diketahui dan apa yang dapat dilakukan peserta didik

e. Memungkinkan guru mengetahui hasil belajar yang penting menurut peserta didik

f. Menjadi bukti otentik hasil belajar peserta didik, orang tua dan masyarakat

\section{Ciri-Ciri Portofolio}

Ciri-ciri portofolio yang baik adalah: 
a. Merefleksikan kejadian atau kegiatan belajarnya yang secara personal bermakna bagi siswa

b. Menunjukkan bukti adanya perkembangan dan peningkatan siswa di semua ranah

c. Mengungkap proses dan produk secara seimbang yaitu isi portofolio menggambarkan proses dan produk belajar

d. Sesuai dengan tujuan pembelajaran dan tujuan kurikuler yaitu disesuaikan dengan kompetensi dasar yang dikembangkan dalam kurikulum

e. Membantu peserta didik memahami kemajuan belajarnya yaitu peserta didik menilai diri sendiri atau penilaian diri

f. Memungkinkan dialog antara peserta didik dan guru dengan orang lain

Hal-hal yang harus diperhatikan dalam penilaian portofolio:

a. Karya siswa adalah benar-benar karya peserta didik itu sendiri. Guru melakukan penelitian atas hasil karya yang dijadikan bahan penilaian portofolio agar hasil karya tersebut merupakan hasil karya yang dibuat oleh peserta didik itu sendiri

b. Saling percaya antara guru dan peserta didik. Dalam proses penilaian guru dan peserta didik harus memiliki saling percaya saling memerlukan dan saling membantu sehingga terjadi proses pendidikan berlangsung dengan baik

c. Kerahasiaan bersama antara guru dan peserta didik. Kerahasiaan hasil pengumpulan informasi perkembangan peserta didik perlu dijaga dengan baik dan tidak disampaikan kepada pihak lain yang tidak berkepentingan sehingga memberi dampak negatif proses pendidikan.

d. Milik bersama antara guru dan peserta didik. Guru dan peserta didik perlu mempunyai rasa memiliki berkas portofolio sehingga peserta didik akan merasa memiliki karya yang dikumpulkan dan akhirnya akan berupaya terus meningkatkan kemampuannya.

e. Kepuasan. Hasil karya portofolio sebaiknya berisi keterangan dan atau bukti yang memberikan dorongan pererta didik untuk lebih meningkatkan diri

f. Kesesuaian. Hasil karya yang dikumpulkan adalah hasil kerja yang sesuai dengan kompetensi yang tercantum dalam kurikulum

g. Penilaian proses dan hasil. Penilaian portofolio menerapkan prinsip proses dan hasil. Proses belajar yang dinilai misalnya diperoleh dari catatan guru tentang kinerja dan karya peserta didik

h. Penilaian dan pembelajaran. Penilaian portofolio merupakan hal yang tak terpisahkan dari proses pembelajaran. Manfaat utama penilaian ini sebagai diagnostik yang sangat berarti bagi guru untuk melihat kelebihan dan kekurangan peserta didik.

Sementara menurut Djemari Mardapi (2004) dalam penilaian portofolio memperhatikan: (1) karya siswa yang dikumpulkan adalah benar-benar karya peserta didik itu sendiri, (2) menentukan contoh pekerjaan mana yang harus dikumpulkan, (3) mengumpulkan dan menyimpan karya siswa, (4) menentukan kriteria untuk menilai portofolio, (5) meminta peserta didik untuk menilai secara terus menerus hasil portofolionya, (6) merencanakan pertemuan dengan peserta didik yang dinilai, (7) dapat melibatkan orang tua dalam penilaian portofolio.

\section{Tujuan dan Manfaat Penilaian Portofolio}

Salah satu keunggulan penilaian portofolio adalah memberikan kesempatan kepada peserta didik untuk lebih banyak terlibat dan peserta didik sendiri dapat dengan mudah mengontrol sejauhmana perkembangan kemampuan yang telah diperolehnya. Jadi peserta didik akan mampu melakukan penilaian diri. Keterampilan untuk menemukan kelebihn dan kekurangannya sendiri serta kemampuan untuk menggunakan kelebihan tersebut dalam 
mengatasi kelemahannya merupakan modal dasar penting dalam proses pembelajaran. Tujuan penilaian portofolio adalah; (a) Menghargai perkembangan peserta didik, (b) Mendokumentasikan proses pembelajaran, (c) Memberi perhatian pada prestasi kerja, (d) Merefleksikan kesanggupan mengambil risiko dan melakukan eksperimentasi, (e) Meningkatkan efektivitas proses pembelajaran, (f) Bertukar informasi antara orang tua peserta didik dengan guru lain, (g) Mempercepat pertumbuhan konsep diri positif peserta didik, (h) Meningkatkan kemampuan refleksi diri, (h) Membantu peserta didik merumuskan tujuan

Penilaian portofolio yang dikemas secara baik dapat memberikan manfaat. Menurut Nurhadi (2005) manfaat penilaian portofolio adalah: (1) guru dapat menilai perkembangan dan kemajuan peserta didik, (2) guru dan wali murid dapat berkomunikasi tentang pekerjaan peserta didik, (3) peserta didik dapat menjadi partner dalam proses penilaian, (4) siswa dapat menemukan bakat dan kemampuannya, (5) penilaian bersifat objektif, (6) penilaian dapat meningkatkan interaksi siswa dan guru untuk mencapai tujuan, (7) penilaian dapat menumbuhkan motivasi siswa untuk belajar, mempunyai kebanggaan, rasa memiliki dan menumbuhkan kepercayaan diri sendiri, (8) penilaian bertujuan untuk mencapai ketuntasan belajar bukan sekedar tuntas materi, (9) guru dan pengawas dapat mengevaluasi program pengajaran (10) penilaian dapat meningkatkan profesionalisme guru (Kunandar,2009). Zaenal Arifin (2009) menjelaskan data yang terkumpul dari waktu ke waktu ini kemudian digunakan oleh guru untuk menilai dan melihat perkembangan kemampuan serta prestasi akademik peserta didik dalam periode tersebut. File portofolio sekaligus akan memberikan umpn balik baik kepada guru maupun kepada peserta didik. Bagi guru file yang berisi prestasi peserat didik ini akan memberikan masukan untuk penilaian proses terutama dalam memperbaiki strategi, metode dan manajemen pembelajaran di kelas. Melalui file portofolio guru dapat mengetahui potensi, karakter, kelebihan dan kelemahan peserta didik. Bagi peserta didik file ini dapat menjadi dasar pijakan untuk mengoreksi dan memperbaiki kelemahan atau kekurangannya dalam proses pembelajaran maupun penguasaannya tentang suatu pokok bahasan atau materi pelajaran tertentu. Proses terjadinya umpan balik sangat dimungkinkan, karena dalam sistem penilaian portofolio, data yang terekam dalam file tidak hanya dikumpulkan saja tetapi dianalisis secara kolaboratif dengan melibatkan guru, peserta didik dan orag tua. Penilaian data melalui pembicaraan secara periodik dengan orang tua peserta didik merupakan progress report yang akurat tentang kemajuan prestasi belajar peserta didik serta perkembangan kepribadiannya.

\section{Teknik Penilaian Portofolio}

Teknik penilaian di dalam kelas memerlukan langkah-langkah sebagai berikut:

a. Jelaskan kepada peserta didik bahwa penggunaan portofolio tidak hanya merupakan kumpulan hasil kerja peserta didik yang digunakan oleh guru untuk penilaian tetapi juga digunakan oleh peserta didik sendiri dan dapat dinilai dengan uang (mempunyai nilai jual bagi mata diklat produktif. Dengan melihat portofolionya peserta didik dapat mengetahui kemampuan keterampilan dan minatnya.

b. Tentukan bersama peserta didik sampel-sampel portofolio apa saja yang akan dibuat. Portofolio antara peserta didik yang satu dan yang lain bisa sama bisa berbeda.

c. Kumpulkan dan simpanlah karya-karya tiap peserta didik dalam satu map atau folder di rumah masing-masing atau loker masing-masing di sekolah

d. Berilah tanggal pembuatan pada setiap bahan informasi perkembangan peserta didik sehingga dapat terlihat perbedaan kualitas dari waktu ke waktu

e. Sebaiknya tentukan aspek-aspek yang akan dinilai dari sampel portofolio beserta pembobotannya bersama para peserta didik sebelum mereka membuat karyanya. Diskusikan cara penilaian kualitas karya para peserta didik 
f. Mintalah peserta didik untuk menilai karyanya secara berkesinambungan. Guru dapat membimbing peserta didik bagaimana cara menilai dengan memberi keterangan tentang kelebihan dan kekurangan. Hal ini dapat dilakukan pada saat membahas portofolio

g. Setelah suatu karya dinilai dan ternyata belum memuaskan kepada peserta didik dapat diberi kesempatan untuk memperbaiki lagi. Namun antara peserta didik dan guru perlu dibuat kontrak atau perjanjian mengenai jangka waktu perbaikan

h. Bila perlu dalam menilai siswa jadwal untuk menyajikan hasil karya siswa tersebut dengan mengundang orang tua maupun masyarakat sehingga orang tua dan masyarakat dapat membantu dan memotivasinya.

\section{Karakteristik Akuntansi}

Akuntansi merupakan bidang kajian yang menghasilkan keterampilan menyajikan laporan keuangan. Keterampilan akan diperoleh peserta didik pada akhir pembelajaran dengan melalui tahapan-tahapan pembelajaran. Tahapan pembelajaran merupakan rangkaian kegiatan yang merupakan urutan kompetensi. Urutan kompetensi tidak dapat diubah kedudukannya. Analisis bukti transaksi merupakan dasar untuk melakukan pengelolaan buku jurnal. Pengelolaan buku jurnal merupakan prasyarat untuk mengelola buku besar dan ketiganya merupakan prasyarat untuk menyelesaikan siklus akuntansi perusahaan. Untuk mencapai kompetensi berikutnya peserta didik harus mempunyai skill passport dari kompetensi sebelumnya. Mengingat pentingnya urutan kegiatan yang menggambarkan perjalanan peserta didik dalam mencapai kompetensi menyusun laporan keuangan, maka portofolio sangat penting untuk disusun guna mengetahui tingkat perkembangan pencapaian kompetensi peserta didik. Penilaian portofolio sangat dianjurkan mengingat hal ini dapat digunakan untuk melihat kemajuan peserta didik dalam mencapai kompetensi akhir yaitu menyusun laporan keuangan.

Penilaian portofolio untuk meningkatkan kualitas pembelajaran, karena selama ini guru cenderung hanya melihat hasil belajar peserta didik dan mengabaikan proses belajarnya sehingga nilai akhir yang dilaporkan hanya menyangkut aspek kognitif. Kelemahan ini tidak dapat dibiarkan saja tetapi harus diupayakan jalan keluarnya. Kondisi di lapangan menunjukkan masih ada sebagian guru Akuntansi yang belum menerapkan penilaian portofolio dengan semestinya. Hal ini ditunjukkan antara lain kebanyakan yang dilakukan guru adalah setiap pekerjaan, tugas atau praktik yang dilakukan oleh peserta didik dikumpulkan, dinilai oleh guru dan dikembalikan pada peserta didik tanpa ada dokumentasi dan evaluasi lebih lanjut. Guru hanya memiliki arsip nilai peserta didik.

\section{Pemanfaatan Penilaian Portofolio dalam Meningkatkan Hasil Belajar Akuntansi}

Model penilaian portofolio dilandasi oleh landasan pemikiran membelajarkan kembali dan merefleksi pengalaman belajar. Menilai adalah mencari informasi tentang pengalaman belajar peserta didik dan informasi tersebut dipergunakan sebagai balikan untuk membelajarkan mereka kembali. Merefleksi pengalaman belajar merupakan satu cara untuk belajar, menghindari kesalahan di masa yang akan datang dan untuk meningkatkan kinerja. Peserta didik dapat bercermin apakah nilai yang mereka peroleh itu menggambarkan pengalaman belajarnya selama ini? Apakah yang telah mereka pelajari berdasarkan pengalaman belajarnya itu? Penilaian juga dapat dijadikan sarana untuk merefleksi kinerja guru. Logikanya peserta didik belajar dan guru membelajarkannya. Jika peserta didik dan guru sudah memperhatikan kedua hal ini maka kualitas hasil belajar akan meningkat. Oleh karena itu kinerja peserta didik berkorelasi dengan kinerja guru.

Model penilaian portofolio mengacu pada sejumlah prinsip dasar penilaian. Prinsip dasar penilaian yang dimaksud adalah penilaian proses dan hasil, penilaian berkala dan sinambung, penilaian yang adil, dan penilaian sosial belajar. Jika prosesnya baik dan 
sempurna, maka dapat diharapkan menuai hasil yang baik pula. Model penilaian portofolio menerapkan prinsip penilaian proses dan hasil sekaligus. Proses belajar yang dinilai misalnya diperoleh dari catatan perilaku harian atau catatan anekdot mengenai sikapnya dalam belajar, antusias tidaknya dalam mengikuti pelajaran, dan sebagainya. Aspek lain dari penilaian proses misalnya menilai tugas terstruktur yang diberikan guru apakah tugas-tugas itu dikerjakan dengan baik atau asal jadi. Model penilaian berbasis portofolio menerapkan prinsip penilaian berkala misalnya setiap selesai satu pelajaran diadakan ulangan, dan setiap catur wulan atau akhir semester diadakan ulangan umum. Model penilaian portofolio juga menerapkan prinsip penilaian bersinambung, adanya kontinuitas penilaian baik penilaian proses maupun penilaian hasil tidak ada yang terputus. Misal harus dilakukan ulangan formatif 1, 2, 3, dan seterusnya hingga diakhiri ulangan umum. Tugas-tugas terstruktur pun harus diberikan secara berkelanjutan dari tugas 1,2,3 dan seterusnya. Demikian catatan harian direkap sejak minggu 1,2,3 dan seterusnya. Laporan aktivitas di luar sekolah juga perlu direkap secara kontinyu dari mulai laporan bulan 1,2,3 dan seterusnya.

Semua indikator penilaian baik dalam menilai hasil maupun proses diperhitungkan dan masing-masing diberi bobot sehingga hasil itu benar-benar mencerminkan kompetensi peserta didik. Jika seorang peserta didik memiliki pengalaman belajar yang baik dalam arti prosesnya ditempuh secara baik maka ia akan memiliki harapan yang besar untuk berhasil dengan baik. Berdasarkan prinsip ini, maka penggunaan penilaian portofolio akan dapat meningkatkan prestasi belajar

Indikator penilaian adalah unsur-unsur pokok yang dapat menjelaskan kemampuan peserta didik setelah menyelesaikan satuan pendidikan tertentu. Banyak indikator yang dapat dipilih tetapi yang paling sensitif adalah hasil ulangan atau tes (tes formatif dan sumatif), penyelesaian tugas-tugas terstruktur, catatan perilaku harian, dan aktivitas di luar sekolah yang mendukung kegiatan belajar. Biasanya nilai tes formatif dan sumatif dicatat di buku daftar nilai. Untuk keperluan penilaian portofolio nilai-nilai ini harus dicatat juga pada portofolio masing-masing dengan mencantumkan kapan tes itu dilaksanakan, mengenai pokok bahasan apa dan berapa nilai yang diperoleh peserta didik. Oleh karena itu berkas penilaian atau lembar jawaban setelah diperiksa dan diberi nilai dikembalikan lagi kepada peserta didik untuk selanjutnya didokumentasikan pada portofolionya maing-masing. Tugastugas terstruktur adalah tugas yang harus dikerjakan peserta didik untuk mendalami atau memperluas penguasaan materi pelajaran. Tugas-tugas tersebut diberikan secara berkala setiap satu satuan pelajaran. Tugas dapat berupa antara lain mengerjakan soal-soal latihan pada lembar kegiatan siswa (LKS), menyusun makalah, melakukan pengamatan lapangan, tugas wawancara. Cara mengerjakannya secara kelompok atau individual. Logikanya jika peserta didik dapat menyelesaikan tugas dengan baik maka penguasaan materi pelajaran akan lebih baik. Catatan perilaku harian peserta didik dapat positif ataupun negatif. Dalam catatan tersebut ditulis nama peserta didik, perilaku yang muncul positif atau negatif dan keterangan mengenai kapan dan dimana kejadian tersebut. Secara berkala, misalnya satu minggu sekali perilaku peserta didik tadi dicatat oleh guru pada portofolio mereka masing-masing, dengan tujuan agar mereka menyadarinya dan merupakan refleksi. Laporan aktivitas di luar sekolah. Masyarakat dan lingkungan sekitar sebaiknya dijadikan laboratorium untuk belajar. Oleh karena itu guru hendaknya meminta para peserta didik untuk melaporkan aktivitas mereka di luar sekolah yang mendukung belajar.

Portofolio ini bukan hanya dimanfaatkan oleh guru dalam rangka menentukan nilai akhir masing-masing peserta didik, tetapi dapat dipergunakan oleh peserta didik sendiri untuk melakukan refleksi dan oleh orang tua untuk melihat perkembangan anak mereka. Penggunaan portofolio bertujuan (1) melakukan pengecekan indikator-indikator perkembangan belajar siswa, (2) memantau perkembangan kemampuan belajar peserta didik baik memantau hasil maupun proses belajarnya, (3) memberikan penghargaan untuk yang 
sangat istimewa dan memberikan dorongan bagi peserta didik yang kemampuan belajarnya lamban.

Meskipun penilaian portofolio dapat digunakan untuk meningkatkan hasil belajar namun tidak terlepas dari kelemahan. Kelemahan portofolio ini adalah:

1. Hasil penilaian menunjukkan korelasi antara nilai portofolio dengan tes tertulis rendah

2. Portofolio mungkin tidak merupakan karya peserta didik sendiri tetapi juga ada bantuan dari teman saudara atau orangtua

3. Memakan waktu dan tenaga bagi guru untuk memilih tugas portofolio menyusun portofolio bersama peserta didik dan mengoreksi bersama peserta didik

4. Memerlukan biaya dan tempat untuk mengoleksi dan menyimpan portofolio dengan baik

Kelemahan ini dapat diatasi dengan merencanakan, dan memantau proses penyusunan dan penilaian portofolio dengan baik.

\section{Penutup.}

1. Penilaian portofolio adalah suatu pendekatan atau model penilaian yang bertujuan untuk mengukur kemampuan peserta didik dalam membangun dan merefleksi suatu pekerjaan/tugas atau karya melalui pengumpulan bahan -bahan yang relevan dengan tujuan dan keinginan yang dibangun peserta didik sehingga hasil pekerjaan tersebut dapat dinilai dan dikomentari oleh guru dalam periode tertentu.

2. Manfaat penilaian portofolio adalah: (1) guru dapat menilai perkembangan dan kemajuan siswa, (2) guru dan wali murid dapat berkomunikasi tentang pekerjaan siswa, (3) siswa dapat menjadi partner dalam proses penilaian, (4) siswa dapat menemukan bakat dan kemampuannya, (5) penilaian bersifat objektif, (6) penilaian dapat meningkatkan interaksi siswa dan guru untuk mencapai tujuan, (7) penilaian dapat menumbuhkan motivasi siswa untuk belajar, mempunyai kebanggaan, rasa memiliki dan menumbuhkan kepercayaan diri sendiri, (8) penilaian bertujuan untuk mencapai ketuntasan belajar bukan sekedar tuntas materi, (9) guru dan pengawas dapat mengevaluasi program pengajaran(10) penilaian dapat meningkatkan profesionalisme guru

3. Pemanfaatan penilaian portofolio dalam meningkatkan hasil belajar dapat dilihat dari landasan pemikiran diterapkannya penilaian portofolio, prinsip penilaian portofolio, dan indikator penilaian portofolio. Landasan pemikiran diterapkannya penilaian portofolio adalah membelajarkan kembali dan merefleksi pengalaman belajar peserta didik. Prinsip penilaian portofolio adalah penilaian proses dan hasil pembelajaran, penilaian berkesinambungan. Indikator penilaian portofolio yang meliputi: tes formatif dan sumatif, tugas terstruktur, catatan perilaku peserta didik, dan aktivitas peserta didik di luar sekolah yang mendukung belajar. Berdasarkan indikator ini penilai dapat membuat kesimpulan sejauh mana seorang peserta didik telah belajar dan berapa nilai yang adil untuknya

\section{Daftar Pustaka}

Dasim Budimansyah. (2002) Model Pembelajaran dan Penilaian Portofolio. Bandung: PT. Genesindo

Depdiknas. (2007). Model Penilaian Kelas Kurikulum Berbasis Kompetensi. Jakarta: Pusat Kurikulum Balitbang Depdiknas 
Djemari Mardapi. (2004). Penyusunan Tes Hasil Belajar. Yogyakarta: Program Pascasarjana UNY

Kunandar. (2002). Guru Profesional Implementasi KTSP dan Sukses dalam Sertifikasi Guru Jakarta: PT Rajawali.

Zaenal Arifin. (2009). Evaluasi Pembelajaran Prinsip Teknik Prosedur. Bandung: PT Remaja Rosdakarya 